\title{
Using Utilitarian Plants for Lemur Conservation
}

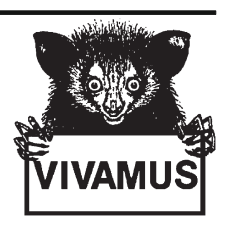

\section{Cathlin Konersmann, et al. [full author details at the end of the article]}

Received: 2 September 2020 / Accepted: 6 January 2021 / Published online: 5 March 2021

(C) The Author(s) 2021

\begin{abstract}
Nature and species conservation often conflict with intensive natural resource or land use. Many protected areas are too small for long-term conservation of viable vertebrate populations, especially in Madagascar, and forests are subject to exploitation for a variety of natural resources. Trying to exclude people from the use of these resources has not been successful during economic, natural, or political crises or when human population growth outruns any development effort. People need economic and other benefits, and conservation measures have to account for these needs. We compiled native and introduced tree, shrub, and herbaceous species used by both people and native vertebrates for three regions, covering the domains of the dry, transitional, and humid forest of Madagascar. We carried out semistructured interviews and group discussions in 12 different villages in each study region in November 2017. People listed 139 utilitarian plant taxa. Our literature search revealed that 72 of these plant species and 13 genera used by people, were also used by 208 different terrestrial vertebrates including 58 lemur species. Application of the Forest Landscape Restoration approach with a combination of exotic and native plant species used by both people and animals could increase the economic value of restored forest habitats for people, thus providing incentives for forest conservation. Plantations of mixed utilitarian trees and shrubs could be integrated into agricultural landscapes. Among landliving vertebrates, lemurs seem to benefit most from this approach. These measures might contribute to a successful array of biodiversity conservation in anthropogenic landscapes.
\end{abstract}

Keywords Agroforestry · Ethnobotany · Forest landscape restoration · Forest restoration · Madagascar $\cdot$ Strepsirrhines $\cdot$ Tree plantations

\section{Introduction}

The United Nations declared 2021-2030 the "Decade of Ecosystem Restoration," aiming to reverse degradation in ecosystems worldwide (Gann et al. 2019). This serves

Cathlin Konersmann, Fanambinantsoa Noromiarilanto and Yedidya R. Ratovonamana contributed equally to this work.

Handling Editor: Joanna Setchell. 
the achievement of international development targets as stated in the Sustainable Development Goals and more specifically in the New York Declaration on Forests and the Global Bonn Challenge concerning the protection and maintenance of forests across Africa. This political support is needed urgently to foster restoration in the world's biodiversity hotspots that have suffered from excessive habitat destruction, such as the native forests of Madagascar (Brinkmann et al. 2014; Harper et al. 2007; Waeber et al. 2015, 2016; Zinner et al. 2014). The African Forest Landscape Restoration Initiative (AFR100), a country-driven and African-led effort, aims to bring 100 million ha of forests and degraded forest landscape under restoration by 2030. As part of this Initiative, Madagascar has pledged to restore 4 million ha of degraded forest landscapes via the Forest Landscape Restoration approach by 2030.

Slash-and-burn agriculture remains the primary economic activity for many households, as opportunities for agricultural intensification are limited, and forested land is openly accessible in Madagascar (Gardner et al. 2016a, b; Hume 2006; Raharimalala et al. 2010; Styger et al. 2007). Over the past century, fallow periods became too short to ensure recovery of vegetation and soil conditions, resulting in increasing pressure on natural resources and declining agricultural productivity. The speed of fallow vegetation recovery and the changes in soil fertility of slash-and-burn cultivation sites has been well documented for a variety of sites (De Wilde et al. 2012; Gay-des-Combes et al. 2017; Klanderud et al. 2010; Leprun et al. 2009; Raharimalala et al. 2010; Styger et al. 2007; Zwartendijk et al. 2017). The restoration and transformation of fallow land to more productive permanent agricultural fields often failed, due to the high work load associated with sustainable cultivation techniques (manure and compost management) and further constraints such as limited resources for external inputs and marketing opportunities for agricultural products (Hume 2006).

At least in the eastern moist forests, natural forest gaps can regenerate well with native pioneer trees such as Harungana madagascariensis or Dombeya spp. (e.g., Martinez and Razafindratsima 2014). However, when the loss of tree cover is followed by landslides, mimicking slash-and-burn practices and fallow land, there are many cases in which the open land has been colonized by genera such as Rubus or Aframomum that form monospecific covers that seem to prevent the natural forest from regenerating (C. Welch, pers. comm.; Goodman et al. 2018). In the domain of the dry forest, regeneration after total clearance seems to follow three trajectories: natural forest regeneration (very slow), mostly monospecific stands of Ziziphus spp., or savannah covered by various grasses of limited value for livestock (Genini 1996). Thus, the species initiating a succession seem to be crucial for its further development.

Starting from degraded land that is no longer used by people, successions could be initiated with plants of possible use for people and the native fauna. To support the unique flora and fauna of biodiversity hotspots, forest restoration should favor native tree species. Yet, the profound local knowledge of indigenous plant species is still underexplored (e.g., Andriamparany et al. 2014) and from what is known scientifically, forest restoration with native trees is challenging due to higher costs, slower growth, and a lack of scientific species-specific knowledge of growth conditions (Birkinshaw et al. 2009; Lavialle et al. 2015). Also, given the high dependency of people on ecosystem services from forests and the pressure on forest resources by the rapidly growing human population, reforestation 'just for animals' may neither be acceptable for people nor sustainable (Gardner et al. 2016a, b). In contrast, reforestation using a 
handful of fast-growing tree species, such as various Eucalyptus and Acacia spp., has conservation value by providing the physical substrate for corridors and taking the pressure off the remaining forests (Andriamandimbiarisoa et al. 2015; De Wilde et al. 2012; Gérard et al. 2015; Irwin et al. 2010). However, these plantations do not contribute much to restoring functional habitats that can provide multiple ecosystem services. Thus, we are left with the inconsistency that, on the one hand, ecological forest restoration is good for the native fauna, but it provides too few ecosystem services for local people. On the other hand, plantations with exotic species provide financial revenues and some ecosystem services to local people, but too few benefits for animals. In response to this, many decision-makers have embraced the approach of Forest Landscape Restoration (FLR) in recent years, which seeks to reconcile biodiversity conservation and provision of ecosystem services for local people (Holloway 2003; Mansourian et al. 2017).

Our objective was to make better use of the local knowledge of the Malagasy inhabitants on the importance and usage of native plants and identify plant species of local importance that are also valuable for the native fauna. For this, we summarize the results of village surveys that could be relevant for forest restoration in three different regions of Madagascar, covering dry deciduous forest of the west, humid forest of the east, and a transition zone in the north of Madagascar. The goal of the study was to combine the human needs for forest resources and services with the objectives of nature and species conservation.

\section{Methods}

\section{Study Area}

We conducted the study in the regions of Menabe (Kirindy, western dry deciduous forest), Diana (transitional forest in the north of Madagascar), and Alaotra-Mangoro (Andasibe, eastern humid forest). Kirindy and Andasibe are villages associated with long-term biodiversity studies in these areas. We use these names in this publication as they are best known to people. Names of all villages and their coordinates are listed in the Electronic Supplementary Material [ESM] Table SI. All three study regions have experienced forest loss and forest fragmentation, making them important candidates for restoration (Figs. 1 and 2).

Menabe/Kirindy The Menabe region is part of the dry deciduous forest of coastal western Madagascar. The climate is characterized by pronounced seasonality with little or no rain from April to November, followed by a rainy season from December to March. Annual precipitation averages $c a .950 \mathrm{~mm}$ and has increased by about $0.5 \%$ per year since 1981. Mean annual temperature in Morondava is $24.7^{\circ} \mathrm{C}$ (Goodman et al. 2018; Sorg and Rohner 1996). The region suffers from one of the highest deforestation rates of the country (Zinner et al. 2014). Main crops are maize, cassava, groundnuts, and different bean varieties. Agriculture is based on slash and burn cultivation. Fallow land is colonized rapidly by secondary grassland or by Ziziphus spp., forming monospecific thickets (Genini 1996).

Diana The Diana region is located in northern Madagascar and represents a very heterogeneous region with annual rainfall ranging from 1000 to $2000 \mathrm{~mm}$. The study 


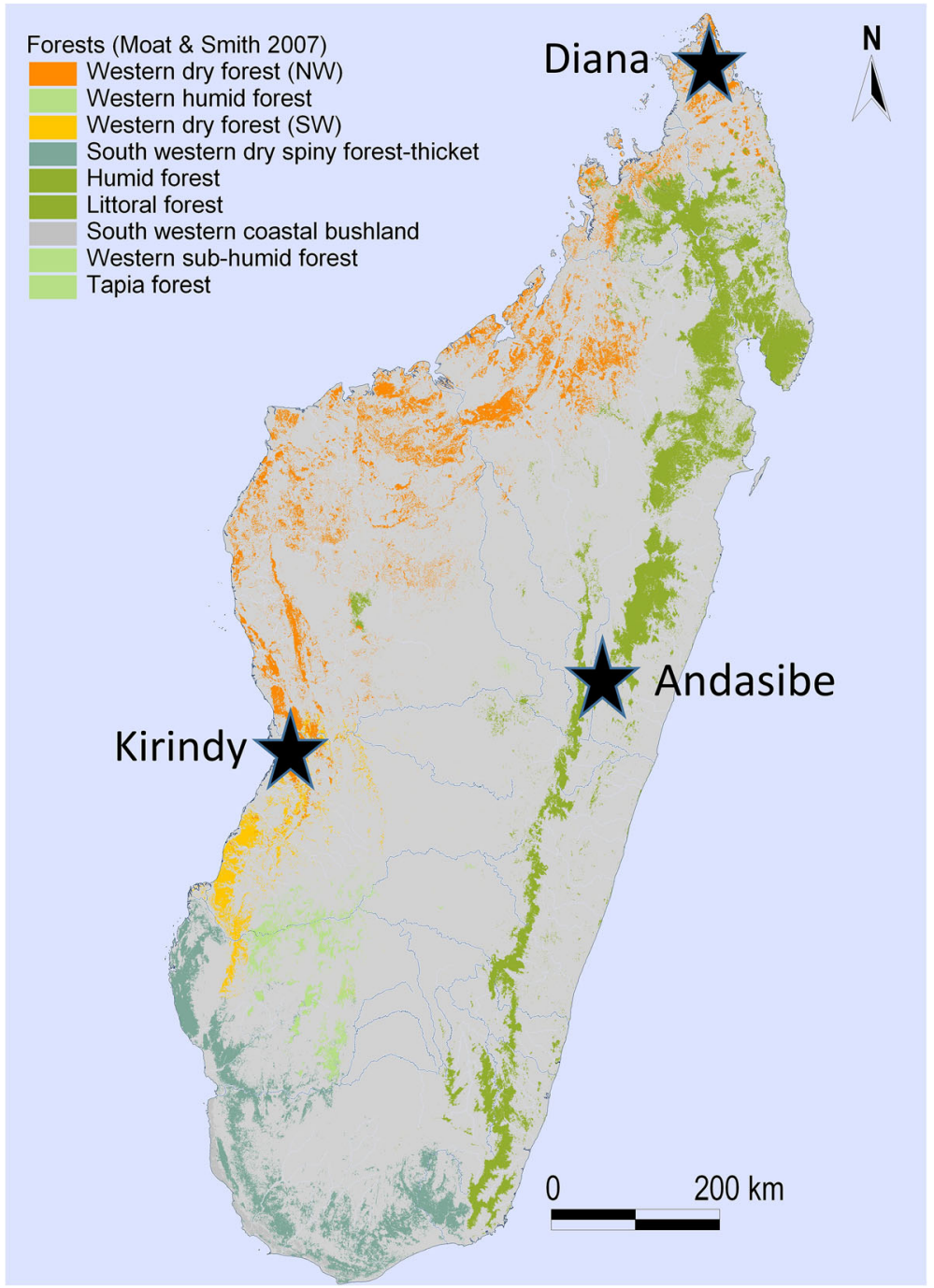

Fig. 1 Location of the selected study regions. Modified from Moat and Smith (2007).

villages are situated in the drier parts of the region dominated by deciduous forest with annual rainfall of about $1200 \mathrm{~mm}$, falling mostly between November and April. Daily mean temperature fluctuates between $20^{\circ}$ and $31^{\circ} \mathrm{C}$ (Goodman et al. 2018). The main crop is rice. Some villages generate income through community-based eucalyptus tree plantations, installed in 1996 to supply the regional capital with charcoal (GIZ/ GREEN-Mad 2007).

Alaotra-Mangoro/Andasibe The study villages are located in the Andasibe region. Natural forest belongs to moist evergreen forest with around $1700 \mathrm{~mm}$ of rain per year, mostly falling between November and April. Daily mean temperature varies 14.5$23.6^{\circ} \mathrm{C}$ (Goodman et al. 2018). Rice is the most important crop. 


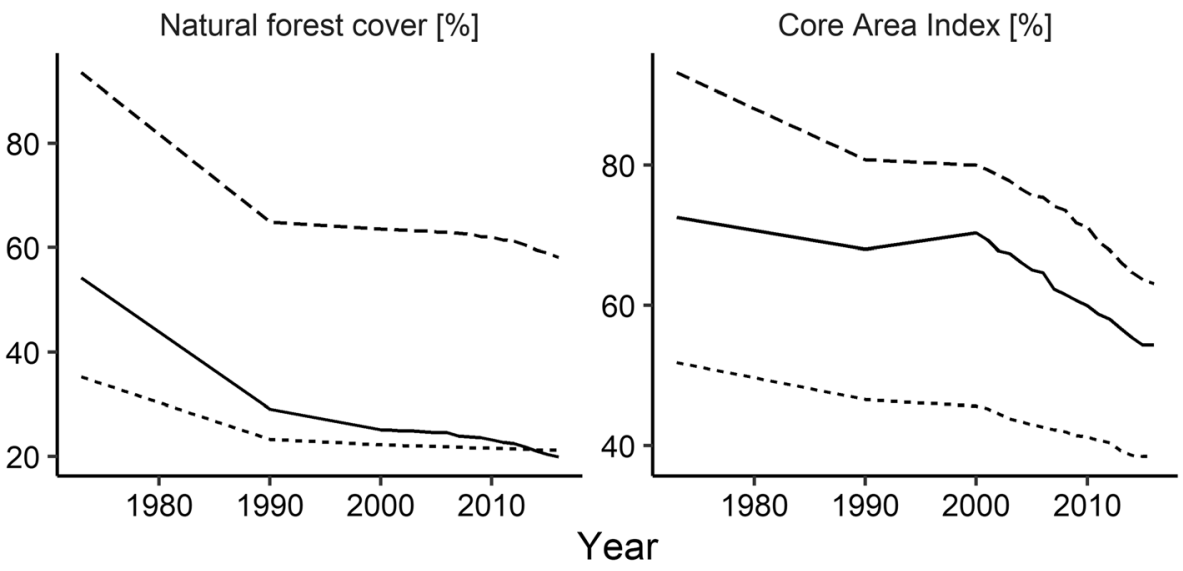

- Andasibe -... Diana --- Kirindy

Fig. 2 Development of natural forest cover (left) and forest fragmentation (right) between 1973 and 2016 in three study regions in Madagascar. For 1973-2000, we used forest cover maps from Vieilledent et al. (2018). For 2001-2016, we produced annual forest cover maps by combining the forest cover map of the year 2000 provided by Vieilledent et al. (2018) and updated annual tree cover loss maps from Hansen et al. (2013). Forest fragmentation is expressed as the Core Area Index, that is, the ratio of forest core area to the total forest area in a study region. We calculated forest core area as the area that is further than a depth-of-edge distance of $90 \mathrm{~m}$ from the forest perimeter (McGarigal and Marks 1995).

\section{Data Collection and Analysis}

Based on recommendations of organizations working in the different areas (Diana: PAGE GIZ; Andasibe: Mitsinjo; Kirindy: Centre National de Formation, d'Education et de Recherche en Environnement et Forestière [CNFEREF]), we carried out surveys in 12 different villages in each study region in November 2017 (ESM Table SI). The mean ( \pm standard deviation) number of inhabitants per village was $805( \pm 494, N=10)$ in Diana, $636( \pm 450, N=12)$ in Andasibe, and $1452( \pm 875, N=12)$ in Kirindy. The "village" survey was based on semistructured interviews and group discussions at the village level (Bernard 2011). We informed the president and village elders about the pending surveys prior to the actual meetings. The Malagasy authors of this study ran the meetings, supported by local staff. All communication was in Malagasy. Meetings were open to all villagers interested in participating, but we assured that at least half of the participants were not older than 50 years. We considered age important to avoid samples biased toward age groups with specific economic or management experiences (e.g., older people no longer involved in everyday activities). We did not consider gender. Both men and women participated in the surveys but participation was biased toward males. Separate discussions with men and women would have been desirable but could not be organized within the scope of the study. Questions concerned the use of natural resources, historical developments, socioeconomic, health, and cultural issues. We report only the use of natural resources here. For this, we asked people to name plants of local importance according to predefined categories that either contribute to ecosystem services (crops, cash-crops, medicinal plants, wood resources, nonwood products of the forest) or are unwanted invasive plants (weeds). In each category, we formulated questions without further specification, translated as follows: 
Which plant products do you sell in the market? Which wild growing plants do people collect for food? Which medicinal plants do you use? What are the most important species used for charcoal? Are there plants (weeds) that you would like to get rid of? Which plants do you grow?

We translated local Malagasy plant species names into scientific names using personal knowledge and published lists (e.g., Schatz 2001; Sorg 1996). Plant vernacular names can vary between villages and even people from the same village. We did not consider plants for which a vernacular name resulted in more than two possible plant species, and species that could not be identified at least to the genus level.

We took information on plant use from the literature. We used the most up-to-date compilation of lemur food plants (Steffens 2020) to check whether lemurs consume any given plant species. We supplemented the data with data for other vertebrate taxa by searches in Web of Science, Google Scholar, books, and journals of regional relevance.

\section{Ethical Note}

Prior to the surveys, the president and village elders were informed about the intended surveys and asked for approval. The survey was carried out only with their consent. The identities of participants were not noted and therefore will not be disclosed. Participants were not pressured or forced to answer any question if they were not willing to.

Data Availability The datasets analyzed during the current study are available from the corresponding author on reasonable request.

\section{Results}

People named 240 different plant species of interest to them. Of these, we could identify 118 to species level. We identified a further 21 to the level of genera that were characteristic enough to be used for further analyses, such as Adansonia spp. (containing only endemic baobabs of Madagascar), Dalbergia spp. (also containing mostly endemic species of precious wood), or Dioscorea spp. (yam varieties found in native forests).

Of the 139 plant taxa mentioned in the village surveys that we could identify precisely enough to search the literature for their use by animals, 72 plant species and 13 genera were used by a total of 208 different terrestrial vertebrate species (Tables I and II). Apart from goats, cattle, introduced rats (Rattus sp.) and mice (Mus sp.) and the introduced myna (Acridotheres tristis) all other species are native to Madagascar. The literature database is most comprehensive for lemurs. It includes 58 lemur species associated with the plant species reported by the villagers. Most of the vertebrate species (131 out of 208) included were not in the "threatened" IUCN Red list categories (Vulnerable, Endangered, Critically Endangered), but 50 of the 58 lemur species included fell into one of the threatened categories.

Excluding weeds and crops, at least 56 plant taxa are of interest to people. These include native and introduced herbaceous and woody species. People listed only five 
Table I Number of vertebrate species associated with plant taxa named as of interest to people in three study regions in Madagascar

\begin{tabular}{llllll}
\hline & Food & Habitat & Food and habitat & Total & $\begin{array}{l}\text { Number of threatened species } \\
\text { and \% (based on total) according } \\
\text { to IUCN Red List }\end{array}$ \\
\hline Amphibians & 0 & 30 & 0 & 30 & $4(13 \%)$ \\
Reptiles & 4 & 20 & 3 & 21 & $6(29 \%)$ \\
Birds & 18 & 66 & 12 & 72 & $6(8 \%)$ \\
Bats/flying foxes & 3 & 9 & 3 & 9 & $3(33 \%)$ \\
Lemurs & 57 & 25 & 24 & 58 & $50(86 \%)$ \\
Rodents & 10 & 0 & 0 & 10 & $1(10 \%)$ \\
Other mammals & 6 & 3 & 1 & 8 & 0 \\
Total & 99 & 153 & 44 & 208 & $70(33.7 \%)$ \\
\hline
\end{tabular}

"Other mammals" include tenrecs, shrews, carnivores, the bush pig, goats, and cattle. "Threatened" includes the IUCN Red List categories Vulnerable, Endangered, and Critically Endangered

herbaceous plants of value to them, which they do not plant on purpose. Woody species represent the majority of utilitarian plants, not planted specifically, but used opportunistically over the year (Fig. 3).

\section{Discussion}

Given the lack of investment options in Madagascar, fallow land taken out of the agricultural production could be used for conservation measures by initiating succession toward the restoration of native forests, including utilitarian plants at all successional stages. This would reduce the threat of succession being arrested at a certain stage. As it is unlikely that people will give up productive land for forest restoration our suggestion of using plants of dual use (usable by people and native animals) aims to restore fallow, unproductive land.

Once deforested, the first objective of restoration is likely to control soil erosion, maintain soil fertility, and grow pioneer plants that will provide the environment for seedlings of trees (Diemont et al. 2006; Klanderud et al. 2010). Herbs usually represent the first stages of natural succession (Raharimalala et al. 2010; Styger et al. 2007). Since herbaceous species are poorly represented in the data we compiled (Table II), we cannot speculate on the first steps of restoring fallow land. However, we are confident that local people have suggestions that can be followed. Later on, legume trees might be good candidates, as they fix nitrogen from the air. The multipurpose Tamarindus indica provides food and shelter for many native animal species and is a prime option for the drier parts of the country, although growth rates seem to be low (Ranaivoson et al. 2015). For humid forests, mango and litchi provide fruit for people and animals and Harungana madagascariensis is fast growing and can quickly cover degraded areas, providing food for birds and lemurs while serving medicinal purposes for humans (Birkinshaw et al. 2009; Rakotoarivelo et al. 2015; Steffens 2020). Adding 


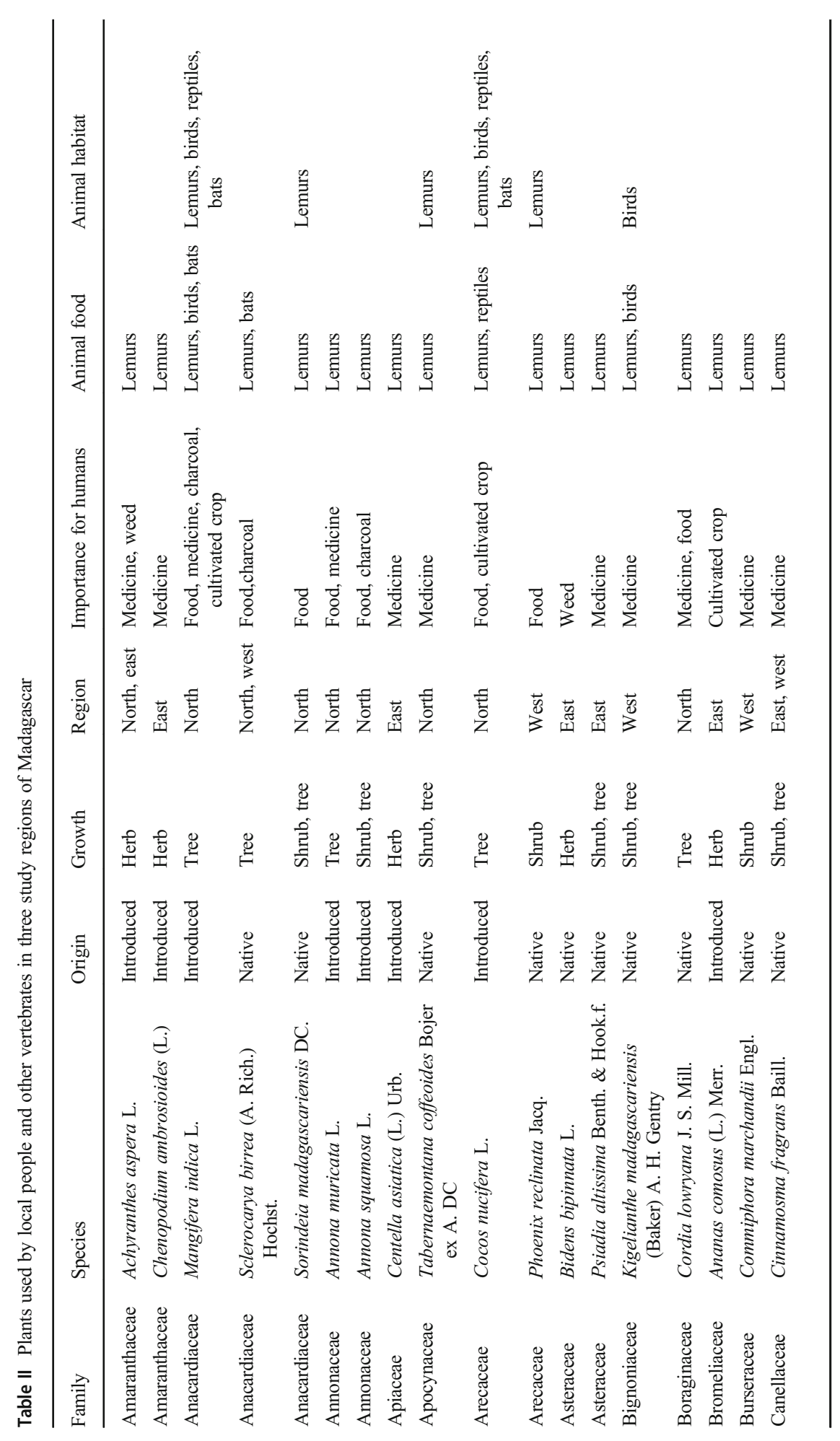




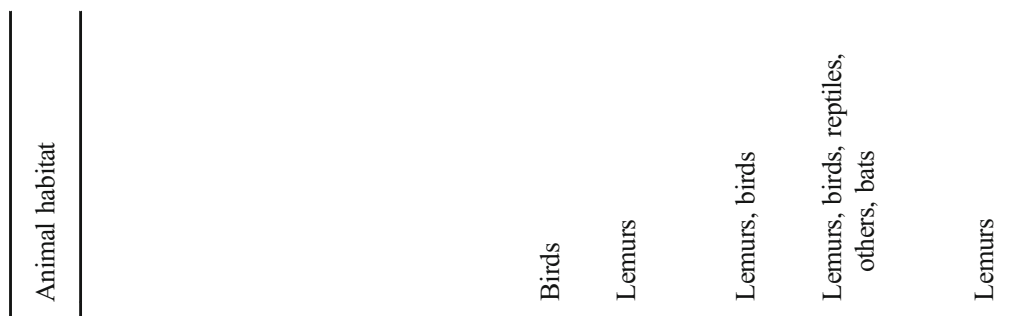

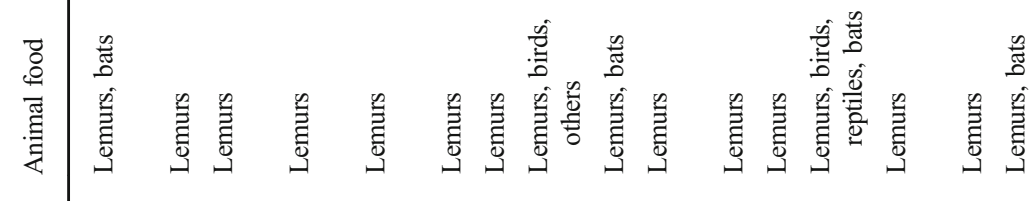

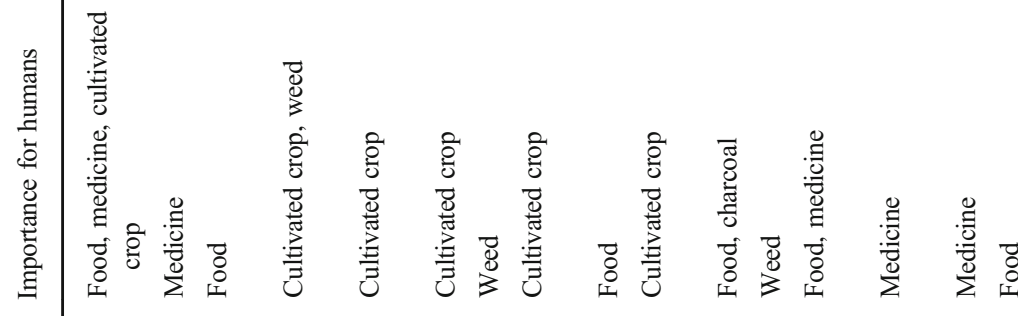

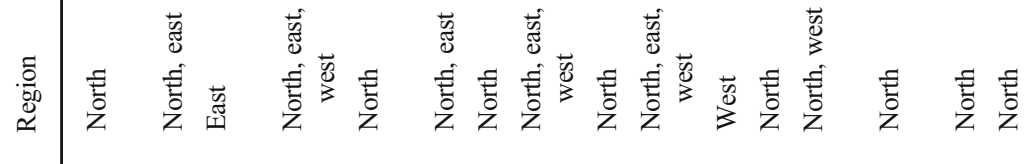

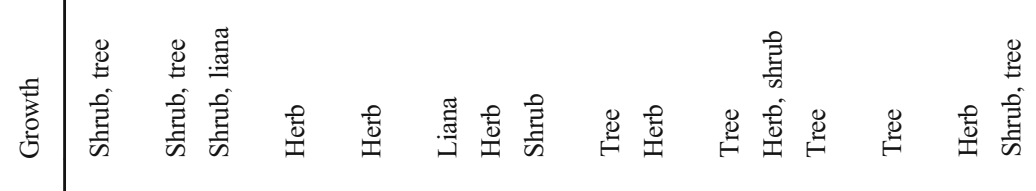

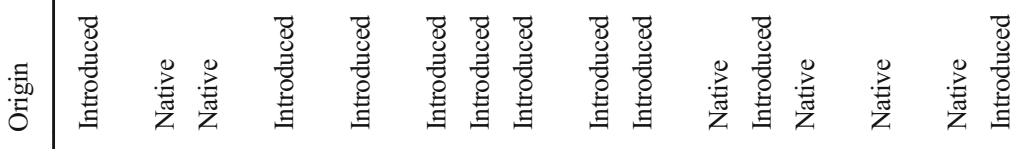

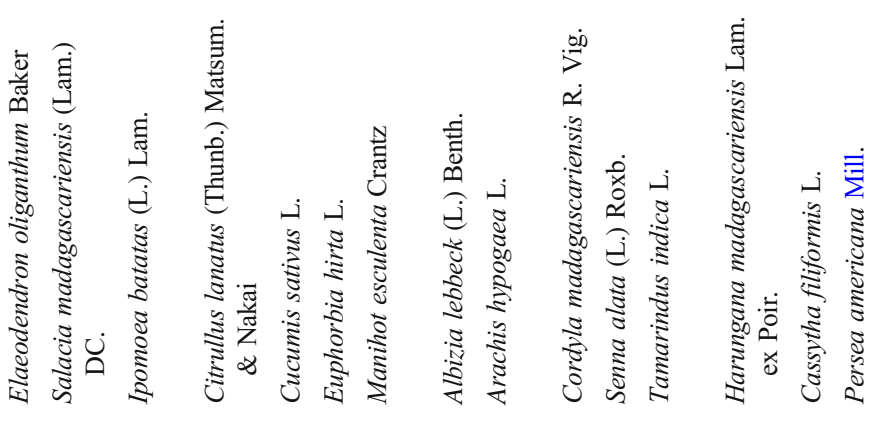

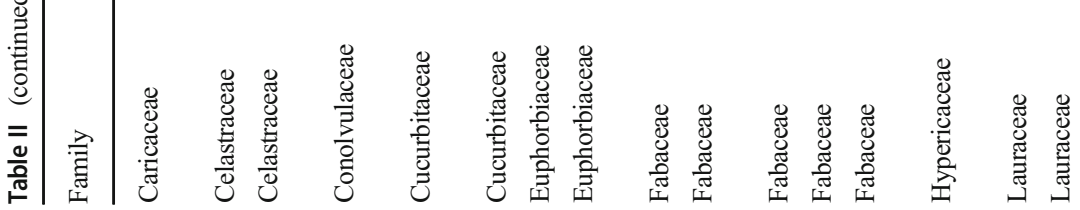




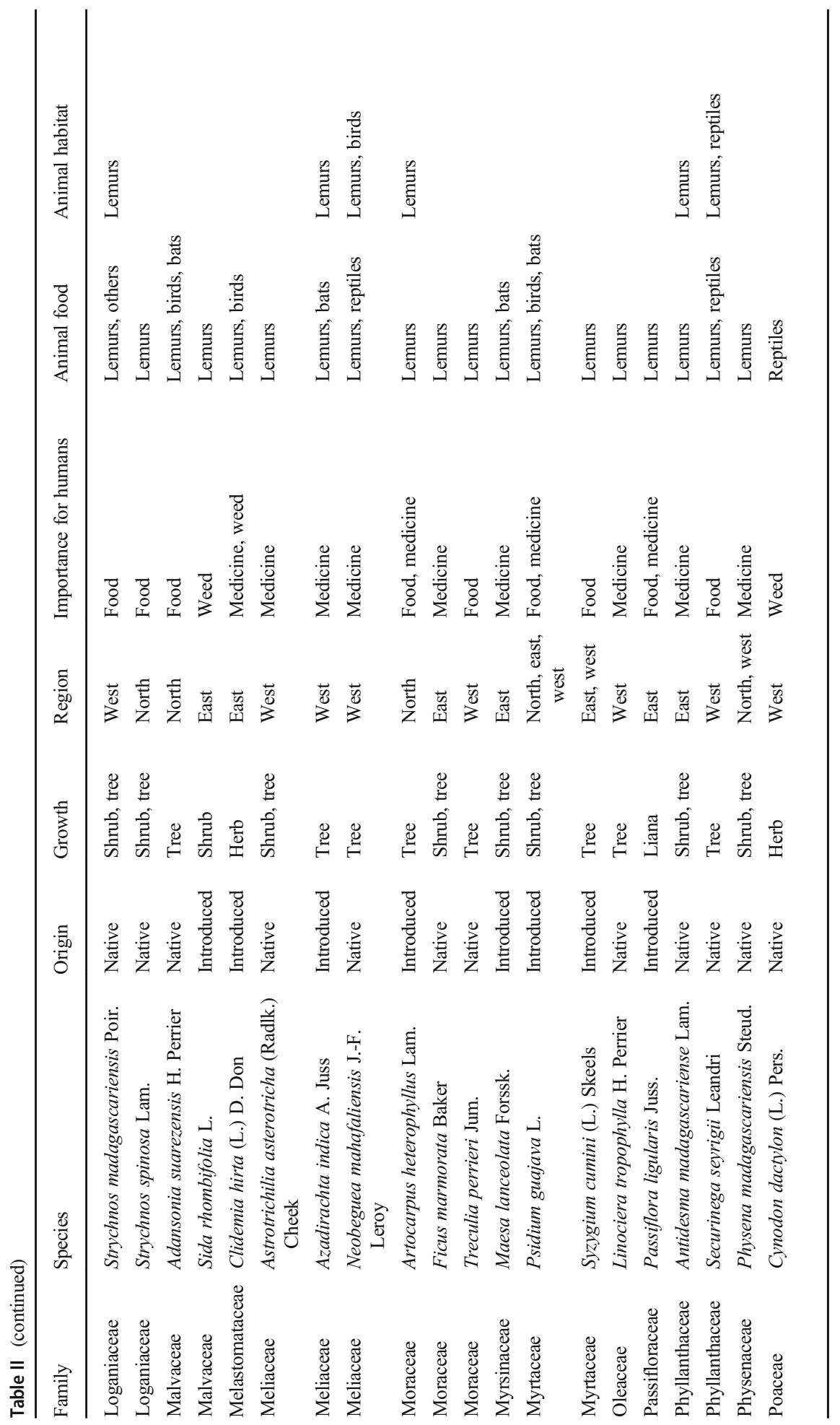




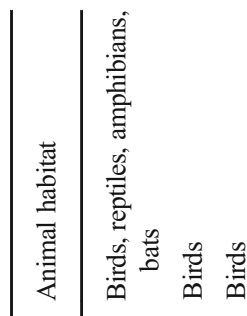

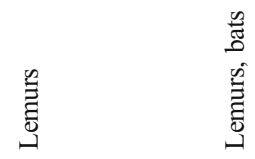

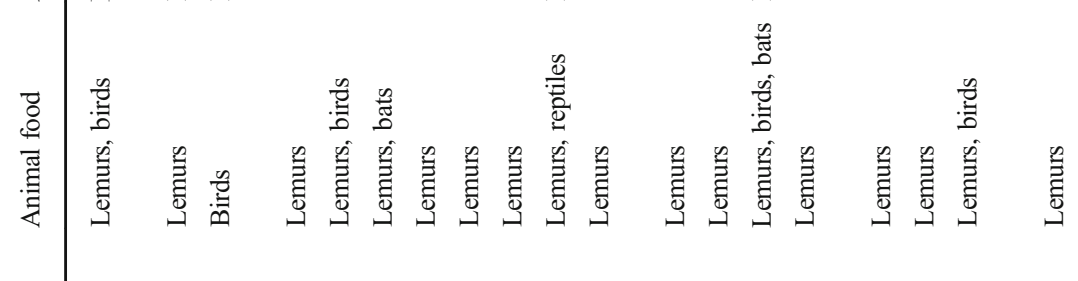

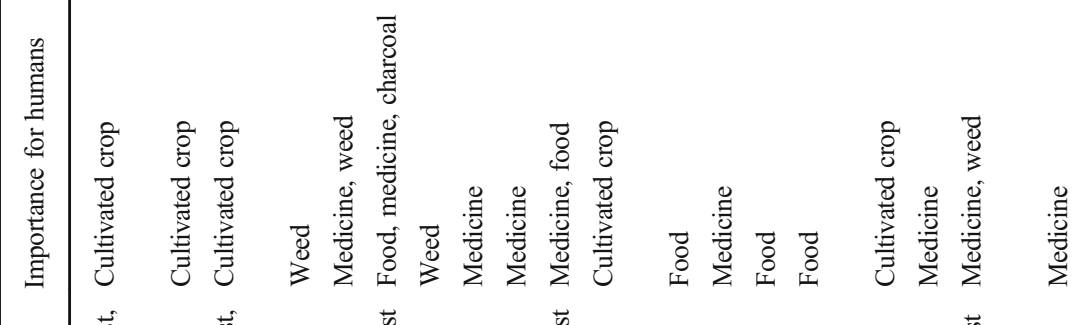

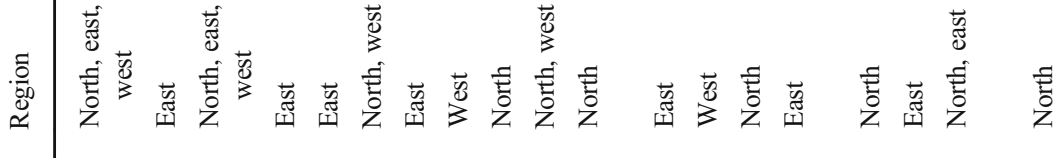

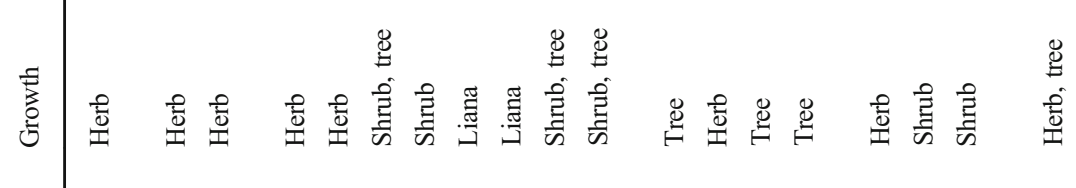

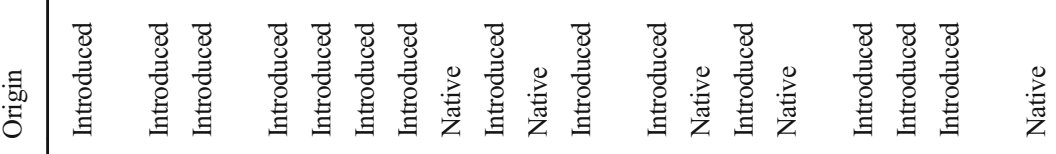
章

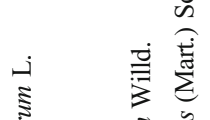

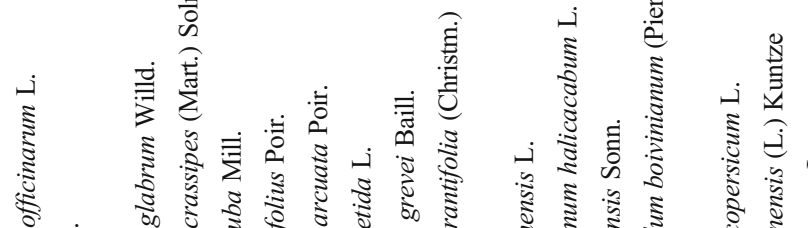

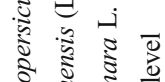

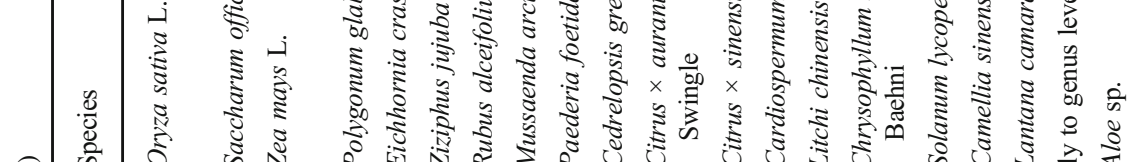

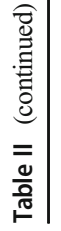

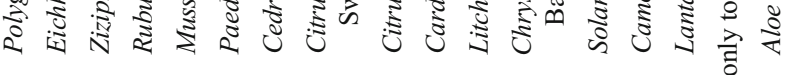

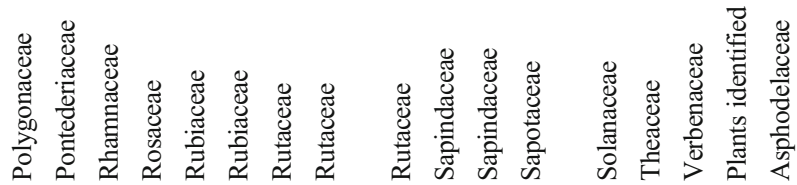




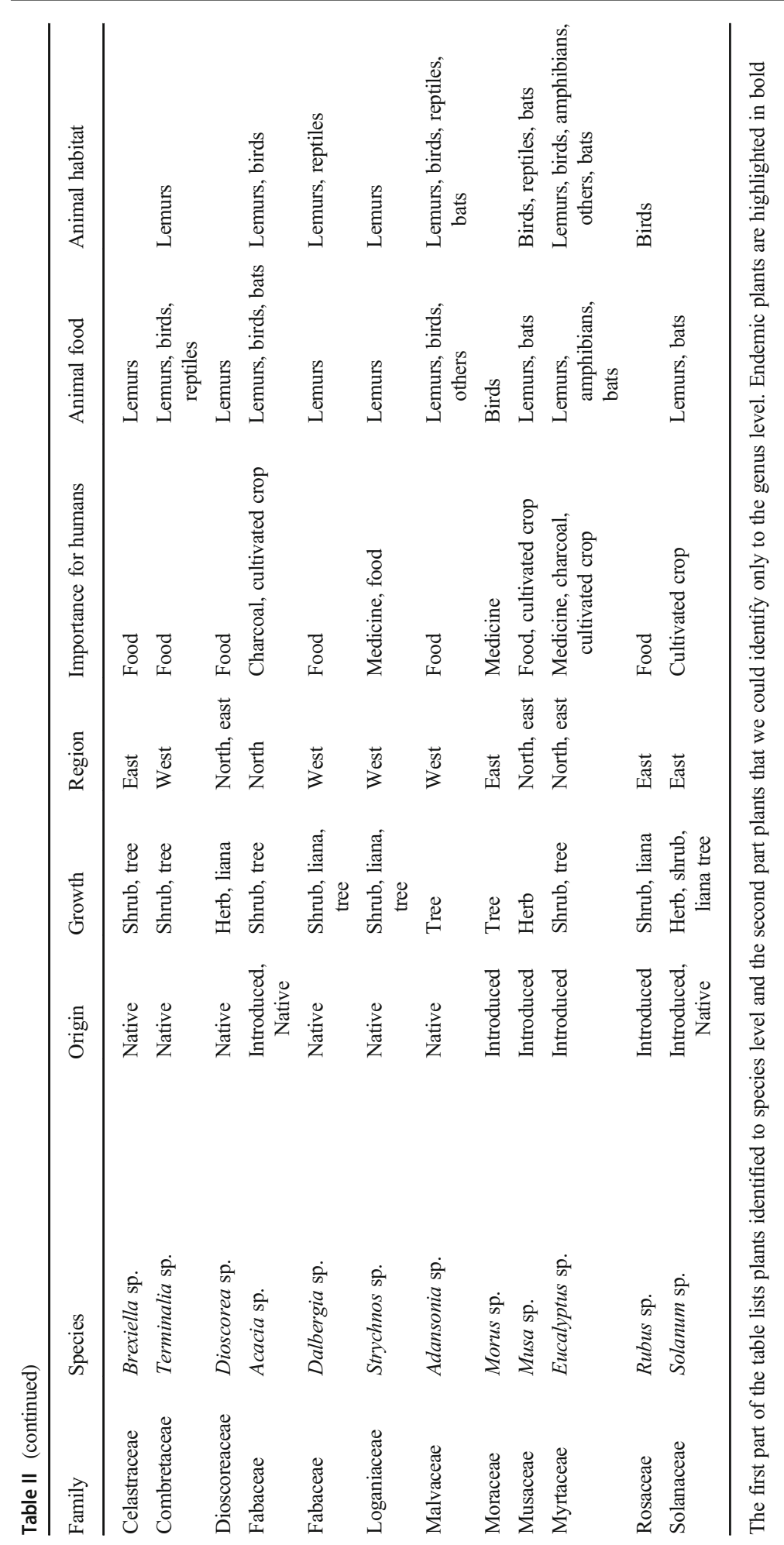




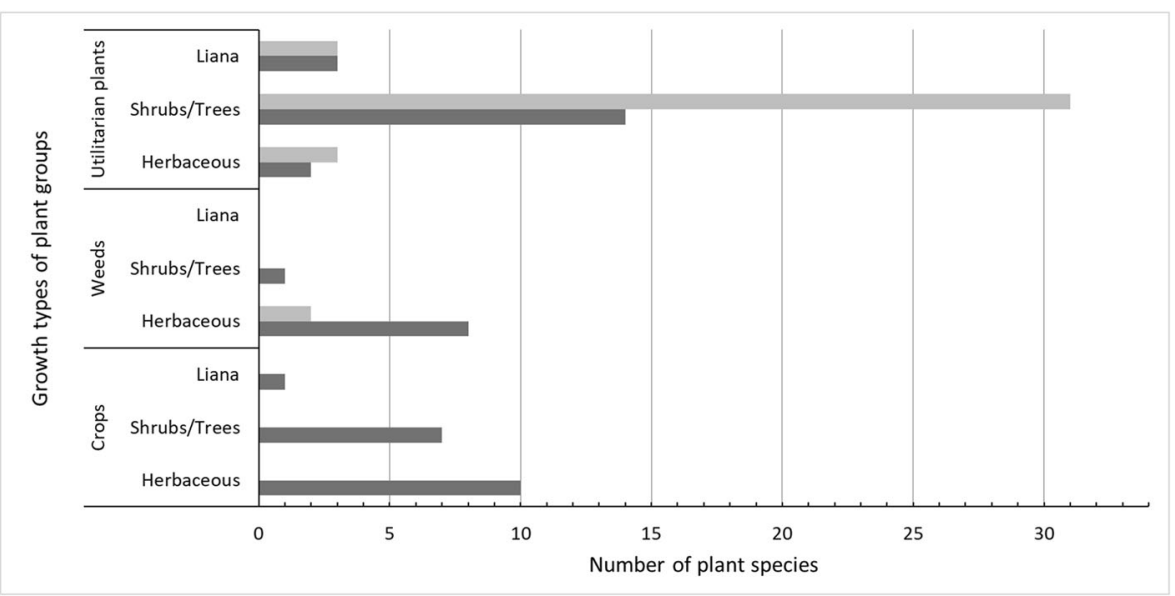

Fig. 3 Number of important plant species for local people and native vertebrates by growth form and plant group (crops, weeds, and utilitarian plants) in three study regions in Madagascar; dark grey = introduced plant species, light grey $=$ native plant species.

plants with cultural and traditional values, such as tamarinds or baobabs, could further diversify the restoration and might add a "sense of place" component that protects forests beyond economic interests. In any case, it is crucial to come to a better understanding of the successional stages in regenerating Malagasy ecosystems by considering local knowledge (De Wilde et al. 2012; Ehrensperger et al. 2013; Gaydes-Combes et al. 2017; Klanderud et al. 2010; Leprun et al. 2009; Rabenantoandro et al. 2007; Raharimalala et al. 2010; Styger et al. 2007; Zwartendijk et al. 2017).

Adding native trees to reforestation projects has the potential to increase ecological complexity and ecosystem services (Brown et al. 2013; Ganzhorn 1987; Gérard et al. 2017; Holloway 2003; Lavialle et al. 2015; Martin et al. 2009, 2012; Rafidison et al. 2020; Zemp et al. 2019). However, they provide fewer direct financial benefits and risk adding disservices, such as antagonists to pollinators or increased herbivory (Wielgoss et al. 2014). Combining the various issues, we argue that forest rehabilitation using a mix of native and exotic species can be a good balance between benefits for people and benefits for the native fauna. By adding more native utilitarian plants or plants of cultural value, rehabilitated forests might be valued more by people and thus might have a higher chance of surviving and possibly developing into substitutes for the original forest (Fritz-Vietta et al. 2011). However, for such a balanced selection of rehabilitation species, we need to integrate scientific and local (practical) knowledge of the growth conditions and usage of native plants.

According to the present study, lemurs seem to be the group of vertebrates that would benefit most from this type of forest rehabilitation. Lemurs used almost all plant species we identified unambiguously and represented more than half of all vertebrates associated with utilitarian trees. More than $80 \%$ of these lemur species fall into one of the "threatened" IUCN Red List categories. This matches the general classification of lemurs as one of the most threatened taxa on earth (Schwitzer et al. 2014). The other vertebrate groups are poorly represented and mostly with species that are not considered threatened. This may be a sampling artefact, as few studies on nonlemur 
vertebrates have been completed in nonnative forests in these regions (Gardner et al. 2016a, b; Irwin et al. 2010; Martin et al. 2009, 2012; Ndriantsoa et al. 2017; Wilmé 2014).

An example of a reforestation project focusing not solely on the protection of species but also considering the needs of local people in southeast Madagascar was reported by Manjaribe et al. (2013). They planted a corridor consisting of three types of plants. The main part of the corridor consisted of plant species consumed by black-and-white ruffed lemurs (Varecia variegata), the remaining parts were divided into a timber and a nontimber tier, including plant species most frequently used by the local community for fuel production or construction, as well as a source of food or other products of commercial value. While there are plenty of examples of native animals using crop and forest plantations (e.g., Chapman et al. in press; Gardner et al. 2010; Irwin et al. 2010; Schwitzer et al. 2011), we are unaware of any example that explicitly uses plants of interest for people and animals alike and thus avoids the issue of the two "parties" competing for limited space. The plantation of utilitarian trees around the forestry station of Ampijoroa in northwestern Madagascar at colonial times, comes closest to the concept of multiuse plantations (fruit, timber, and other economic value trees) for people, but also designed to extend suitable habitat for lemurs (Ganzhorn and Abraham 1991).

Though utilitarian plants and crops offer a large, yet unexploited potential for restoration, care must be taken to avoid conflicts of interest. Though systematic surveys are lacking, anecdotal reports indicate that people in Madagascar do not tolerate animals eating their crops, such as Hapalemur spp. eating rice plants in the humid forests (Martinez 2008; T. Eppley, pers. comm.) or parrots and finches eating crops in the western part of Madagascar. Fruit trees seem to be less of a problem as long as people do not embark on industrial fruit production for the national or international market. In this context, mixed or fully utilitarian forests such as plantations or agroforestry systems could benefit local communities and function as habitat extensions or corridors for vertebrates including lemurs. For example, lemurs use vanilla and cocoa plantations in northern Madagascar (Hending et al. 2018; Webber et al. 2020). However, when animals such as birds, flying foxes, or lemurs feed on fruits of trees also used by humans, they can transmit zoonotic diseases through contamination of fruits by feces. Diseases can range from salmonellosis to more dangerous viral diseases (Iehlé et al. 2007; Joffrin et al. 2020). This problem may not be as pronounced in plants used by people for medicinal purposes or charcoal production. Species targeted for wood or charcoal production or for the international furniture market may be good candidates to be used by many vertebrate species as well as by humans. These can include many species of precious wood, such as Dalbergia spp. that not only have suffered from illegal exploitation (the "rosewood crisis"; Wilmé et al. 2020) over the last few years, but have also traditionally been the most appreciated wood for cooking (Razafintsalama et al. 2014).

Apart from direct, unwanted, interactions with humans, vertebrates can contribute substantially to the dispersal of seeds and thus accelerate the invasion of species that may be of value to people and animals but are not wanted from a conservation point of view. These include neem trees (Azadirachta indica), guava (Psidium guajava), Ziziphus spp., or Morus spp. (Carrière et al. 2008; DeSisto et al. 2020; Kull et al. 2012). Moreover, many of the more than 20 plant taxa people listed as "weeds" (e.g., 
Clidemia hirta, Lantana camara, and Rubus spp.) are dispersed by frugivores. However, the perception of "weed" depends on context and might change over time (Kull et al. 2012; McConnell et al. 2015; Tassin and Kull 2015). For example, Sorghum bicolor (L.) Moench was planted as a crop well adapted to dry conditions in the west, but the harvests were compromised by birds and thus the cultivation was abandoned. Whatever was left in the region is now considered a "weed." Clidemia hirta is known as an invasive species that colonizes open areas quickly and park authorities make great efforts to remove it. Yet, Clidemia hirta allowed the frugivorous black-and-white ruffed lemur (Varecia variegata) to survive in forest fragments after a cyclone had blown down their fruit trees (Ratsimbazafy et al. 2002) and plays a major role in restoring rainforest in northern Madagascar (Martinez and Razafindratsima 2014). Similarly, guava (Psidium guajava) is invasive in parts of Madagascar, but this exotic plant was observed to play a key role in the survival of collared brown lemurs (Eulemur collaris) in the Mandena Conservation Zone, southeast Madagascar (Donati et al. 2020; Kull et al. 2012). Though not covered by the present study, the introduced Opuntia spp. is an example of repeated changes in its appreciation. Currently, this plant is considered an invasive weed in the dry parts of Madagascar but is used by lemurs and guaranteed the survival of people and their livestock during droughts in the past (Jolly 2004). It has recently been identified as a possible source of substantial economic income through the production of essential oils (Hänke et al. 2018), so may yet become desirable. Acacia spp. may include invasive species that are hard to control or remove once they have invaded natural systems, but not all species are invasive and as fast-growing legumes, that are fire resistant and retardant, they have a high potential to restore soil fertility and provide firewood from denuded areas. In many areas largely void of vegetation cover and with an exhausted seed bank, these "weeds," which are valuable to people, might be a first step to stop erosion, restore soil fertility (especially legumes), and thus provide the basis for the development of more complex ecosystems (Gay-desCombes et al. 2017; Randriamalala et al. 2015; Zwartendijk et al. 2017).

To our knowledge, the concept of designing restoration projects focusing on plants to be used by humans and animals alike is lacking for Madagascar and other parts of the world. Although a thorough ecological and economic cost-benefit analysis must be made before applying the concept, the present study illustrates that there is a treasure of options and knowledge in the local human communities that should be paid more thorough attention.

\section{Conclusion}

The village surveys led to two major insights: First, there are many plant species of interest to people and native vertebrates alike, which could be used for restoration and that could provide economic income at various temporal scales, ranging from years (native yams) to decades and even centuries (native precious wood). The known diversity of possible plants is rarely used in restoration projects. Second, the surveys did not provide a complete list of plants that could be or were used by people. The whole aspect of honey production has not been considered (Eco-Services Consulting 2017; Fohavelo and Gulley 2000), and the medicinal plants mentioned in the surveys comprise only a fraction of the plants that people actually use (e.g., apart from their 
crops, people from Menabe listed 22 plants of value in the present compilation, while a previous study in the region described 151 species collected and used for many more different purposes [Favre 1990, 1996]). Similarly, an ethnobotanical study in 13 villages close to Andasibé reported 209 medicinal plants used by people (Rakotoarivelo et al. 2015) while our survey revealed only 34 species for the 12 villages we visited. Apart from the obviously incomplete sampling of information, we had to discard about a third of the data provided by the villagers because we could not link their names to our system. This exemplifies how little we know about the possibilities available. It also illustrates a huge, yet unexploited, knowledge that could be used for restoration without additional costs, except that of listening to local people (Marie et al. 2009).

Supplementary Information The online version contains supplementary material available at https://doi.org/ 10.1007/s10764-021-00200-y.

Acknowledgments We thank Giuseppe Donati, Kate Hill, and Aimee Oxley for having invited us to the symposium in Oxford and to write this contribution. The ideas were developed over many years of most fruitful collaboration between the universities of Antananarivo and Hamburg with support by Madagascar National Parks and WWF. PAGE GIZ, Mitsinjo, and the Centre National de Formation, d'Education et de Recherche en Environnement et Forestière (CNFEREF) helped greatly in completion of the village surveys. We thank Giuseppe Donati, Joanna Setchell, and the reviewers for valuable comments to improve the manuscript. The work was supported by the German Ministry for Education and Research (BMBF 01LC1708) and the Center for a Sustainable University (KNU), University of Hamburg.

Authors' contributions $\mathrm{CN}, \mathrm{FN}, \mathrm{YRR}, \mathrm{KB}, \mathrm{SK}, \mathrm{DK}, \mathrm{KJES}$ and JUG conceived and designed the study. FN, YRR, KB, SK and DK conducted fieldwork. CK, FN and KB compiled the data. CK and KJES analyzed the data. CT, KS and JUG wrote the manuscript; other authors provided editorial advice.

Funding Open Access funding enabled and organized by Projekt DEAL.

Open Access This article is licensed under a Creative Commons Attribution 4.0 International License, which permits use, sharing, adaptation, distribution and reproduction in any medium or format, as long as you give appropriate credit to the original author(s) and the source, provide a link to the Creative Commons licence, and indicate if changes were made. The images or other third party material in this article are included in the article's Creative Commons licence, unless indicated otherwise in a credit line to the material. If material is not included in the article's Creative Commons licence and your intended use is not permitted by statutory regulation or exceeds the permitted use, you will need to obtain permission directly from the copyright holder. To view a copy of this licence, visit http://creativecommons.org/licenses/by/4.0/.

\section{References}

Andriamandimbiarisoa, L., Blanthorn, T., Ernest, R., Ramanamanjato, J.-B., \& Randriatafika, F. (2015). Habitat corridor utilisation by the gray mouse lemur, Microcebus murinus, in the littoral forest fragments of southeastern Madagascar. Madagascar Conservation \& Development, 10, 144-150.

Andriamparany, J. N., Brinkmann, K., Jeannoda, V., \& Buerkert, A. (2014). Effects of socio-economic household characteristics on traditional knowledge and usage of wild yams and medicinal plants in the Mahafaly region of south-western Madagascar. Journal of Ethnobiology and Ethnomedicine, 10, 82.

Bernard, H. R. (2011). Research methods in anthropology: Qualitative and quantitative approaches. Lanham: AltaMira Press, Rowman \& Littlefield. 
Birkinshaw, C., Andrianjafy, M., \& Rasolofonirina, J. J. (2009). Survival and growth of seedlings of 19 native tree and shrub species planted in degraded forest as part of a forest restoration project in Madagascar's highlands. Madagascar Conservation \& Development, 4, 128-131.

Brinkmann, K., Noromiarilanto, F., Ratovonamana, R.-Y., \& Buerkert, A. (2014). Deforestation processes in south-western Madagascar over the past 40 years: What can we learn from settlement characteristics? Agriculture, Ecosystems and Environment, 195, 231-243.

Brown, K. A., Johnson, S. E., Parks, K. E., Holmes, S. M., Ivoandry, T., et al (2013). Use of provisioning ecosystem services drives loss of functional traits across land use intensification gradients in tropical forests in Madagascar. Biological Conservation, 161, 118-127.

Carrière, S. M., Randrianasolo, E., \& Hennenfent, J. (2008). Aires protégées et lutte contre les bioninvasions: Des objectifs antagonistes? Le cas de Psidium cattleianum Sabine (Myrtaceae) autour du parc national de Ranomafana à Madagascar. VertigO - La revue en sciences de l'environnement, 8, 1-14.

Chapman, C. A., Bicca-Marques, J. C., Dunham, A. E., Fan, P., Fashing, P. J., et al. (in press). Primates can be a rallying symbol to promote tropical forest restoration. Folia Primatologica.

DeSisto, C. M. M., Park, D. S., Davis, C. C., Ramananjato, V., Tonos, J. L., \& Razafindratsima, O. H. (2020). An invasive species spread by threatened diurnal lemurs impacts rainforest structure in Madagascar. Biological Invasions, 22, 2845-2858.

De Wilde, M., Buisson, E., Ratovoson, F., Randrianaivo, R., Carrière, S. M., \& Lowry, P. P. (2012). Vegetation dynamics in a corridor between protected areas after slash-and-burn cultivation in southeastern Madagascar. Agriculture, Ecosystems \& Environment, 159, 1-8.

Diemont, S. A. W., Martina, J. F., Levy-Tacher, S. I., Nigh, R. B., Lopez, P. R., \& Golicher, J. D. (2006). Lacandon Maya forest management: Restoration of soil fertility using native tree species. Ecological Engineering, 28, 205-212.

Donati, G., Campera, M., \& Balestri, M. (2020). Life in a fragment: Evolution of foraging strategies of translocated collared brown lemurs, Eulemur collaris, over an 18-year period. American Journal of Primatology, 82, e23106.

Eco-Services Consulting (2017). Etude d'inventaire et analyse des plantes mellifères et évaluation de leur potentiel de production dans les zones de production de miel d'Ambanja et de ses environs. Antananarivo: GIZ, Helvetas.

Ehrensperger, T., Urech, Z. L., Rehnus, M., \& Sorg, J. P. (2013). Fire impact on the woody plant components of dry deciduous forest in Central Menabe. Madagascar. Applied Vegetation Science, 16, 619-628.

Favre, J.-C. (1990). Evaluations qualitatives et quantitatives des utilisations villageoises des ressources en forêt dense sèche: Etude de cas du village de Marofandilia dans la région de Morondava/Madagascar. ETH Zürich, Arbeitsberichte Internationale Reihe, 90, 1-59.

Favre, J.-C. (1996). Traditional utilization of the forest. In J. U. Ganzhorn \& J.-P. Sorg (Eds.), Ecology and economy of a tropical dry forest in Madagascar (pp. 33-40). Primate Report, 46-1). Göttingen: Erich Goltze.

Fohavelo, A., \& Gulley, J. (2000). Les espèces de plantes mellifères des alentours de Marofandilia. Lemur News, 5, 14-16.

Fritz-Vietta, N. V. M., Ferguson, H. B., Stoll-Kleemann, S., \& Ganzhorn. J. U. (2011). Conservation in a biodiversity hotspot: Insights from cultural and community perspectives in Madagascar. In F. E. Zachos \& J. C. Habel (Eds.), Biodiversity hotspots (pp. 209-233). Heidelberg: Springer.

Gann, G. D., McDonald, T., Walder, B., et al (2019). International principles and standards for the practice of ecological restoration. 2nd ed. Restoration Ecology, 27, 3-46.

Ganzhorn, J. U. (1987). A possible role of plantations for primate conservation in Madagascar. American Journal of Primatology, 12, 205-215.

Ganzhorn, J. U., \& Abraham, J.-P. (1991). Possible role of plantations for lemur conservation in Madagascar: Food for folivorous species. Folia Primatologica, 56, 171-176.

Gardner, C. J., Gabriel, F. U. L., St John, F. A. V., \& Davies, Z. G. (2016a). Changing livelihoods and protected area management: A case study of charcoal production in south-west Madagascar. Oryx, 50, 495-505.

Gardner, C. J., Jasper, L. D., Eonintsoa, C., Duchene, J. J., \& Davies, Z. G. (2016b). The impact of natural resource use on bird and reptile communities within multiple-use protected areas: Evidence from sub-arid Southern Madagascar. Biodiversity and Conservation, 25, 1773-1793.

Gardner, T. A., Barlow, J., Sodhi, N. S., \& Peres, C. A. (2010). A multi-region assessment of tropical forest biodiversity in a human-modified world. Biological Conservation, 143, 2293-2300.

Gay-des-Combes, J. M., Robroek, B. J. M., Herve, D., et al (2017). Slash-and-burn agriculture and tropical cyclone activity in Madagascar: Implication for soil fertility dynamics and corn performance. Agriculture Ecosystems \& Environment, 239, 207-218. 
Genini, M. (1996). Deforestation. In J. U. Ganzhorn \& J.-P. Sorg (Eds.), Ecology and economy of a tropical dry forest in Madagascar (pp. 49-55). Primate Report (pp. 46-41). Göttingen: Erich Goltze.

Gérard, A., Ganzhorn, J. U., Kull, C. A., \& Carrière, S. M. (2015). Possible roles of introduced plants for native vertebrate conservation: The case of Madagascar. Restoration Ecology, 23, 768-775.

Gérard, A., Wollni, M., Holscher, D., et al (2017). Oil-palm yields in diversified plantations: Initial results from a biodiversity enrichment experiment in Sumatra. Indonesia. Agriculture Ecosystems \& Environment, 240, 253-260.

GIZ/GREEN-Mad (2007). Le reboisement villageois individuel: Stratégies. In techniques et impacts de GREEN-Mad (MEM-GTZ) dans la région d'Antsiranana Madagascar. Antananarivo: GIZ.

Goodman, S. M., Raherilalao, M. J., \& Wohlhauser, S. (2018). Les aires protégées terrestres de Madagascar: Leur histoire, description et biote / The terrestrial protected areas of Madagascar: Their history, description, and biota. Antananarivo: Association Vahatra.

Hänke, H., Barkmann, J., Müller, C., \& Marggraf, R. (2018). Potential of Opuntia seed oil for livelihood improvement in semi-arid Madagascar. Madagascar Conservation \& Development, 13, $34-44$.

Hansen, M. C., Potapov, P. V., Moore, R., et al (2013). High-resolution global maps of 21 st-century forest cover change. Science, 342, 850-853.

Harper, G. J., Steininger, M. K., Tucker, C. J., Juhn, D., \& Hawkins, F. (2007). Fifty years of deforestation and forest fragmentation in Madagascar. Environmental Conservation, 34, 325-333.

Hending, D., Andrianiaina, A., Rakotomalala, Z., \& Cotton, S. (2018). The use of vanilla plantations by lemurs: Encouraging findings for both lemur conservation and sustainable agroforestry in the Sava region. northeast Madagascar. International Journal of Primatology, 39, 141-153.

Holloway, L. (2003). Ecosystem restoration and rehabilitation in Madagascar. In S. M. Goodman \& J. Benstead (Eds.), The natural history of Madagascar (pp. 1444-1451). Chicago: University of Chicago Press.

Hume, D. W. (2006). Swidden agriculture and conservation in eastern Madagascar: stakeholder perspectives and cultural belief systems. Conservation and Society, 4, 287-303.

Iehlé, C., Razafitrimo, G., Razainirina, J., et al (2007). Henipavirus and Tioman virus antibodies in pteropodid bats. Madagascar. Emerging Infectious Diseases, 13, 159-161.

Irwin, M. T., Wright, P. C., Birkinshaw, C., et al (2010). Patterns of species change in anthropogenically disturbed forests of Madagascar. Biological Conservation, 143, 2351-2362.

Joffrin, L., Goodman, S. M., Wilkinson, D. A., et al (2020). Bat coronavirus phylogeography in the Western Indian Ocean. Scientific Reports, 10, 6873.

Jolly, A. (2004). Lords and lemurs. Boston: Houghton Mifflin Company.

Klanderud, K., Mbolatiana, H. Z. H., Vololomboahangy, M. N., et al (2010). Recovery of plant species richness and composition after slash-and-burn agriculture in a tropical rainforest in Madagascar. Biodiversity and Conservation, 19, 187-204.

Kull, C. A., Tassin, J., Moreau, S., Ramiarantsoa, H. R., Blanc-Pamard, C., \& Carrière, S. M. (2012). The introduced flora of Madagascar. Biological Invasions, 14, 875-888.

Lavialle, J., Carrière, S. M., Miandrimanana, C., Tilahimena, A., Birkinshaw, C. R., \& Aronson, J. (2015). Complementarity of native and introduced tree species: Exploring timber supply on the east coast of Madagascar. Madagascar Conservation \& Development, 10, 137-143.

Leprun, J. C., Grouzis, M., \& Randriambanona, H. (2009). Post-cropping change and dynamics in soil and vegetation properties after forest clearing: Example of the semi-arid Mikea Region (southwestern Madagascar). Comptes Rendus Geoscience, 341, 526-537.

Manjaribe, C., Frasier, C. L., Rakouth, B., \& Louis Jr., E. E. (2013). Ecological restoration and reforestation of fragmented forests in Kianjavato, Madagascar. International Journal of Ecology, 2013, 726275.

Mansourian, S., Stanturf, J. A., Derkyi, M. A. A., \& Engel, V. L. (2017). Forest landscape restoration: Increasing the positive impacts of forest restoration or simply the area under tree cover? Restoration Ecology, 25, 178-183.

Marie, C. N., Sibelet, N., Dulcire, M., Rafalimaro, M., Danthu, P., \& Carrière, S. M. (2009). Taking into account local practices and indigenous knowledge in an emergency conservation context in Madagascar. Biodiversity and Conservation, 18, 2759-2777.

Martin, E. A., Ratsimisetra, L., Laloe, F., \& Carrière, S. M. (2009). Conservation value for birds of traditionally managed isolated trees in an agricultural landscape of Madagascar. Biodiversity and Conservation, 18, 2719-2742.

Martin, E. A., Viano, M., Ratsimisetra, L., Laloë, F., \& Carrière, S. M. (2012). Maintenance of bird functional diversity in a traditional agroecosystem of Madagascar. Agriculture, Ecosystems \& Environment, 149, 1-9. 
Martinez, B. T. (2008). Occurrence of bamboo lemurs, Hapalemur griseus occidentalis, in an agricultural landscape on the Masoala Peninsula. Lemur News, 13, 11-14.

Martinez, B. T., \& Razafindratsima, O. H. (2014). Frugivory and seed dispersal patterns of the red-ruffed lemur, Varecia rubra, at a forest restoration site in Masoala National Park. Madagascar. Folia Primatologica, 85, 228-243.

McConnell, W. J., Vina, A., Kull, C., \& Batko, C. (2015). Forest transition in Madagascar's highlands: Initial evidence and implications. Land, 4, 1155-1181.

McGarigal, K., \& Marks, B. J. (1995). FRAGSTATS: Spatial pattern analysis program for quantifying landscape structure. Portland, OR: U.S. Department of Agriculture, Forest Service, Pacific Northwest Research Station.

Moat, J., \& Smith, P. (2007). Atlas of the vegetation of Madagascar, Atlas de la Végétation de Madagascar. Kew: Kew Publishing, Royal Botanic Gardens.

Ndriantsoa, S. H., Riemann, J. C., Raminosoa, N., Rodel, M. O., \& Glos, J. S. (2017). Amphibian diversity in the matrix of a fragmented landscape around Ranomafana in Madagascar depends on matrix quality. Tropical Conservation Science, 10, 1-16.

Rabenantoandro, J., Randriatafika, F., \& Lowry II, P. P. (2007). Floristic and structural characteristics of remnant littoral forest sites in the Tolagnaro area. In J. U. Ganzhorn, S. M. Goodman, \& M. Vincelette (Eds.), Biodiversity, ecology and conservation of littoral ecosystems in southeastern Madagascar, Tolagnaro (Fort Dauphin) (pp. 65-93). Washington, DC: Smithsonian Institution.

Rafidison, V. M., Rakouth, B., Carrière, S. M., Kjellberg, F., \& Aumeeruddy-Thomas, Y. (2020). Multiple values of isolated and clusters of Ficus tree species protected by Betsileo farmers in rural landscapes in Madagascar: Implications for biodiversity conservation. Biodiversity and Conservation, 29, 1027-1058.

Raharimalala, O., Buttler, A., Ramohavelo, C. D., Razanaka, S., Sorg, J. P., \& Gobat, J. M. (2010). Soilvegetation patterns in secondary slash and burn successions in Central Menabe. Madagascar. Agriculture Ecosystems \& Environment, 139, 150-158.

Rakotoarivelo, N. H., Rakotoarivony, F., Ramarosandratana, A. V., et al (2015). Medicinal plants used to treat the most frequent diseases encountered in Ambalabe rural community. Eastern Madagascar. Journal of Ethnobiology and Ethnomedicine, 11, 68.

Ranaivoson, T., Brinkmann, K., Rakouth, B., \& Buerkert, A. (2015). Distribution, biomass and local importance of tamarind trees in south-western Madagascar. Global Ecology and Conservation, 4, 14-25.

Randriamalala, J. R., Herve, D., Letourmy, P., \& Carrière, S. M. (2015). Effects of slash-and-burn practices on soil seed banks in secondary forest successions in Madagascar. Agriculture Ecosystems \& Environment, 199, 312-319.

Ratsimbazafy, J. H., Ramarosandratana, H. V., \& Zaonarivola, R. J. (2002). How do black-and-white ruffed lemurs still survive in a highly disturbed habitat? Lemur News, 7, 7-10.

Razafintsalama, V., Ramananantoandro, T., Belloncle, C., Rajoelison, G. L., \& Sorg, J.-P. (2014). Utilisations villageoises et potentialités technologiques des bois de forêts secondaires dans le Menabe central, Madagascar. Bois et Forêts des Tropiques, 3202, 59-73.

Schatz, G. E. (2001). Generic tree flora of Madagascar. Kew: Royal Botanic Gardens and St. Louis: Missouri Botanical Garden.

Schwitzer, C., Glatt, L., Nekaris, K. A.-I., \& Ganzhorn, J. U. (2011). Responses of animals to habitat alteration: An overview focussing on primates. Endangered Species Research, 14, 31-38.

Schwitzer, C., Mittermeier, R. A., Johnson, S. E., et al (2014). Averting lemur extinctions amid Madagascar's political crisis. Science, 343, 842-843.

Sorg, J.-P. (1996). Vernacular and scientific names of plants of the Morondava region. In J. U. Ganzhorn \& J. P. Sorg (Eds.), Ecology and economy of a tropical dry forest in Madagascar (pp. 339-346). Primate Report, 46-1). Göttingen: Erich Goltze.

Sorg, J.-P., \& Rohner, U. (1996). Climate and phenology of the dry deciduous forest at Kirindy. In J. U. Ganzhorn \& J.-P. Sorg (Eds.), Ecology and economy of a tropical dry forest in Madagascar (pp. 57-80). Primate Report 46-1). Göttingen: Erich Goltze.

Steffens, K. J. E. (2020). Lemur food plants as options for forest restoration in Madagascar. Restoration Ecology, 28, 1517-1527.

Styger, E., Rakotondramasy, H. M., Pfeffer, M. J., Fernandes, E. C. M., \& Bates, D. M. (2007). Influence of slash-and-burn farming practices on fallow succession and land degradation in the rainforest region of Madagascar. Agriculture Ecosystems \& Environment, 119, 257-269.

Tassin, J., \& Kull, C. A. (2015). Facing the broader dimensions of biological invasions. Land Use Policy, 42, 165-169. 
Vieilledent, G., Grinand, C., Rakotomalala, F. A., et al (2018). Combining global tree cover loss data with historical national forest cover maps to look at six decades of deforestation and forest fragmentation in Madagascar. Biological Conservation, 222, 189-197.

Waeber, P. O., Wilmé, L., Mercier, J.-R., Camara, C., \& Lowry, P. P. I. I. (2016). How effective have thirty years of internationally driven conservation and development efforts been in Madagascar? PLoS ONE, 11, e0161115.

Waeber, P. O., Wilmé, L., Ramamonjisoa, B., et al (2015). Dry forests in Madagascar: Neglected and under pressure. International Forestry Review, 16, 127-148.

Webber, A. D., Solofondranohatra, J. S., Razafindramoana, S., et al (2020). Lemurs in cacao: Presence and abundance within the shade plantations of northern Madagascar. Folia Primatologica, 91, 96-107.

Wielgoss, A., Tscharntke, T., Rumede, A., et al (2014). Interaction complexity matters: Disentangling services and disservices of ant communities driving yield in tropical agroecosystems. Proceedings of the Royal Society B: Biological Sciences, 281, 20132144.

Wilmé, L. (2014). Inventaire ornithologique dans les plantations d'eucalyptus et les terrains incultes de la région Diana, Madagascar. Antananarivo: Eco Consult.

Wilmé, L., Innes, J. L., Schuurman, D., et al (2020). The elephant in the room: Madagascar's rosewood stocks and stockpiles. Conservation Letters, 13, e12714.

Zemp, D. C., Ehbrecht, M., Seidel, D., et al (2019). Mixed-species tree plantings enhance structural complexity in oil palm plantations. Agriculture Ecosystems \& Environment, 283, 106564.

Zinner, D., Wygoda, C., Razafimanantsoa, L., et al (2014). Analysis of deforestation patterns in the Central Menabe, Madagascar, between 1973 and 2010. Regional Environmental Change, 14, 157-166.

Zwartendijk, B. W., van Meerveld, H. J., Ghimire, C. P., Bruijnzeel, L. A., Ravelona, M., \& Jones, J. P. G. (2017). Rebuilding soil hydrological functioning after swidden agriculture in eastern Madagascar. Agriculture Ecosystems \& Environment, 239, 101-111.

\section{Affiliations}

\section{Cathlin Konersmann ${ }^{1}$ • Fanambinantsoa Noromiarilanto ${ }^{2}$ • Yedidya R. Ratovonamana $^{1,2}$. Katja Brinkmann ${ }^{3}$. Kai Jensen ${ }^{4}$. Susanne Kobbe ${ }^{1}$. Michael $\mathrm{Köhl}^{5}$ - Daniel Kuebler ${ }^{5}$. Petra Lahann ${ }^{6} \cdot \mathrm{Kim}_{\text {J. E. Steffens }}{ }^{1} \cdot$ Jörg U. Ganzhorn ${ }^{1}$}

Jörg U. Ganzhorn

ganzhorn@uni-hamburg.de

1 Institute of Zoology, Animal Ecology and Conservation, Universität Hamburg, Hamburg, Germany

2 Département de Biologie et Ecologie Végétale, Faculté des Sciences, Université d'Antananarivo, Antananarivo, Madagascar

3 ISOE - Institute for Social-Ecological Research, Frankfurt am Main, Germany

4 Applied Plant Ecology, Universität Hamburg, Hamburg, Germany

5 Institute for World Forestry, Universität Hamburg, Hamburg, Germany

6 Sector Project International Forest Policy, GIZ, Eschborn, Germany 